Review

\title{
Water Scarcity in Cyprus: A Review and Call for Integrated Policy
}

\author{
Anastasia Sofroniou ${ }^{1, *}$ and Steven Bishop ${ }^{2}$ \\ 1 School of Computing and Technology, University of West London, St Mary's Road, \\ London W5 5RF, UK \\ 2 Department of Mathematics, University College London, Gower Street, London WC1E 6BT, UK; \\ E-Mail: s.bishop@ucl.ac.uk \\ * Author to whom correspondence should be addressed; E-Mail: anastasia.sofroniou@uwl.ac.uk; \\ Tel.: +44-20-8231-2068.
}

External Editor: Davide Viaggi

Received: 30 June 2014; in revised form: 3 September 2014 / Accepted: 9 September 2014 /

Published: 29 September 2014

\begin{abstract}
This article is a study of water scarcity in Cyprus, examining the implications on the demand and supply side of water under the transformations caused by economic development, urbanisation and environmental changes. Measures and actions taken by water stakeholders to tackle the water poverty issue are discussed and assessed, together with possible future solution methods. In the light of the success of global climate models to forecast future conditions and advances in integrated management tools, the suggestion here is the need for a global systems approach to help guide policy decisions.
\end{abstract}

Keywords: Cyprus; water scarcity; water resources; water policy; water management

\section{Introduction}

Water is essential for all social and economic development, as well as for maintaining healthy ecosystems. As the worldwide population grows, our ability to meet the rising demand for water will be challenged, especially when compounded by profligate use. Furthermore, with greater climate variability 
comes flooding and droughts, which places additional pressure on our ability to manage our water resources. Water scarcity may be defined when water resources do not fully satisfy water demand or minimum requirements by all sectors [1,2]. Climatic conditions, the degradation of groundwater and surface water quality, interregional and international conflicts may all contribute to water scarcity $[3,4]$. Water Scarcity is not just a third world problem and in this respect, we focus on the small Eastern Mediterranean island of Cyprus, which can be considered as a microcosm example of dealing with water scarcity in Europe and used to highlight pre-cursers to problems that might be echoed in larger cities and regions across the globe in the future.

Cyprus suffers from the highest water stress level in Europe, particularly in years of excessive drought $[5,6]$. Thus, the issue of water shortage is a key aspect of life in Cyprus where limited supply, urban spread and population growth are all relevant producing an urgent need to control its dependence on precipitation. Historically, wars have been fought due to the desire for sovereignty of water and the loss of this resource meant total capitulation. In ancient times it is not unheard of for large settlements and civilisations to completely disappear when the ground water ran out, such as the Garamantes Berbers in the Saharan region [3]. It has been speculated that water may well become the cause of a new conflicts, with "Water wars" by Starr [4] being perhaps the first alarmist recognition of how scarcity of water could lead to widespread social disruption (also see [5]). In the 1980s, US government intelligence estimated ten places where water wars could break out, with Cyprus being listed amongst those countries [4]. To date there is however, no historical evidence of water wars on the island but the fact that a large portion of the island is occupied by Turkey, again shows how Cyprus can form an excellent test bed for integrated policy scenarios. Water scarcity is a severe issue for both the Greek-Cypriot and Turkish-Cypriot communities and any joint action may be a means to tackling the continuing political division of the island. Thus, possible collaborative scenarios can be regarded as a unique notion of "Water of Peace".

Scarcity may also be a social construct, a product of affluence (think golf courses), expectations (think of daily showers) and customary behaviour, or the consequence of altered supply patterns, stemming from climate change [1]. Water scarcity may lead to social impacts, such as decrease in employment in some sectors and possible migration of industries and people [7]. Not surprisingly though, scarcity predominantly is due to water shortage and it is in the arid and semi-arid regions affected by droughts and variations in climatic conditions, combined with increases in population, economic development and inefficient and wasteful water exploitation, where the problems of water scarcity become most acute [2]. Impacts from climate change will aggravate the status of the existing water resources taking into account surface water, groundwater, rivers, lakes, coastal waters and aquifers [8]. The Intergovernmental Panel on Climate Change Fourth Assessment Report (IPCC-AR4) [9] indicates significant summer warming in South-Eastern Europe and the Mediterranean, while downward trends are associated with the mean annual precipitation [10]. The combined effect of high temperatures and low rainfall means that the eastern Mediterranean region is going to face increasing aridity, as well as a significant threat of desertification much sooner than other countries in Europe $[11,12]$. Such projections illustrate that climate change effects will have serious consequences for the already scarce water resources and for the energy needs of Cyprus. 
Furthermore, climate variability, with longer periods of low rainfall combined with heavy storms requires careful management of the precious water resources.

The aim of this article is to provide a "case study" of water scarcity in Cyprus and to examine the implications on the demand and supply side of water under the transformations caused by economic development, urbanization, and environmental changes. Based upon existing data and results from previous studies, the water management in Cyprus is analysed. Measures and strategic actions taken by local water stakeholders (e.g., the Cyprus Water Development Department, WDD) aiming to make the water resources management more sustainable, are discussed and assessed. Alternative methods such as desalination, water reuse techniques and the concept of virtual water will be described and the decision and implementation processes evaluated. Suggested models would build on the seminal work of Zarchariadis [13], co-worker Zoumides [14] and others who have quantified the elements that contribute to the water cycle and considered the water footprint of different sectors.

\section{Relevant Geographic, Historic and Economic Background}

Cyprus is an island state situated in the north-eastern end of the East Mediterranean basin with an area of $9251 \mathrm{~km}^{2}$ and is the third largest island in the Mediterranean. In 1974, a Turkish invasion led to 37\% of the islands territory being occupied, literally splitting the capital, Nicosia, in half. More recently, strenuous political efforts have been aimed at economic recovery with much of the economy based on services (mostly tourism) and, to a small extent, on agriculture, which of course is potentially the largest user of water, more specifically to date, accounting for $64 \%$ of the island's water resources. The other water consuming sectors are the domestic $(28.4 \%)$, tourism $(4.7 \%)$ and industry sector accounting for $2.9 \%$ of water demands [15].

In 2004, Cyprus became a member of the European Union and, up to 2008, the island enjoyed macroeconomic stability, reflected through various indicators including real GDP growth (3.6\%), inflation (3.6\%) and unemployment (4.4\%), and classified by the International Monetary Fund (IMF) to be among the top 32 advanced economies of the world [16,17]. However, the United States' subprime mortgage crisis in 2007-2008 led to a domino effect with the Cypriot economy going into recession in 2009 with the rate of change of real GDP reaching $-2.4 \%$ in 2012 [17]. In 2012-2013, the position in Cyprus was exasperated by the Greek government-debt crisis, the exposure of Cypriot banks to overleveraged local property companies, the downgrading of the Cypriot government's bond credit rating, the consequential incapability to refund its state expenses from the international markets and the averseness of the government to restructure the distressed Cypriot financial sector. Today, Cyprus Government seeks to guarantee the recovery of economic activity, to preserve the welfare of the population by reestablishing financial sector stability, strengthening public finance sustainability, and implementing structural reforms to support long-run growth, such as a welfare reform providing a guaranteed minimum income for all those in need, an integration of the revenue administration, and a strengthening of the administration's powers to fight tax evasion [16]. 
The official population of Cyprus was estimated at 865,878 at the end of 2012, of which, approximately, 75\% were Greek Cypriots, 10\% Turkish Cypriots, and 15\% were foreign residents [18]. Figure 1a indicates the overall increase in population from 1961 until 2012. After the Turkish invasion in 1974, the total population experienced negative growth up to mid-1977, through war losses, emigration and falling birth rate, but, thereafter, Cyprus saw a population increase. Worldwide, population growth will contribute to water shortages $[2,19,20]$, for instance, in Jordan, due to the population increase and the periodic massive influxes of refugees from neighbouring countries, there has been a huge increase in water demand, and new water resources are needed to counteract the negative water balance between supply and demand [21]. There are no official documents quantifying the contribution of water shortages with respect to the population growth in Cyprus. However, it can be expected that water demand does increase as a result of population growth, tourism development and increased standard of living. In 1996 for instance, the total water demand in the Government controlled areas was $132.5 \mathrm{Mm}^{3}$ with a population record of 666,313 people, thereafter, in 2000 , the total water demand was $265.9 \mathrm{Mm}^{3}$ whilst the population increased to 697,549 and, recently, in 2012, the total water demand share was $275 \mathrm{Mm}^{3}$ whilst the population number reached to 865,878 [18,22]. In Cyprus, rainfall is largely in the winter with about $60 \%$ of the average annual total precipitation falling from December to February. This varies annually between $280 \mathrm{~mm}$ in the central plains to $1000 \mathrm{~mm}$ on the Troodos mountain peak (altitude $1950 \mathrm{~m}$ ) with a mean annual precipitation of $497 \mathrm{~mm}$. The total annual water supply is 2670 million cubic metres $\left(\mathrm{Mm}^{3}\right)$, $86 \%$ of which is lost in evaporation leaving $374 \mathrm{Mm}^{3}$ as useable water, of which $235 \mathrm{Mm}^{3}$ represents surface water and $139 \mathrm{Mm}^{3}$ represents groundwater that replenishes the aquifers [22,23]. Winter rainfall is the main source for the replenishment of water resources since summer rains do not contribute significantly to the recharge, refill of aquifers [24,25]. The small amounts that do fall in summer are rapidly absorbed by the very dry soil or soon evaporated by the high temperatures and low humidity thus, most crops require significant irrigation.

The chart within the figure (Figure 1b) also shows the annual precipitation (in mm) in Cyprus for the years 1961-2012. Historically, in Cyprus, droughts occur every two-to-three successive years due to the decline in rainfall and, moreover, in the last fifty years, drought incidences have increased both in magnitude and frequency.

On independence in 1960, the Government of Cyprus embarked on an ambitious program of tapping the surface waters that used to be lost into the sea, especially with a comprehensive water resources program from 1967 to 1970 with the technical help of the United Nations Development Programme. Under the theme Not a Drop of Water to the Sea, to date the storage capacity of surface reservoirs, dams, has increased by a factor of 53 with more than 100 dams having been constructed on almost all rivers for the country. This means that Cyprus is now ranked first in the ICOLD (International Commission on Large Dams) register, in the area of Europe, with a ratio of fifty large dams for every 10,000 square kilometres. These reservoirs provide a storage capacity of $331.93 \mathrm{Mm}^{3}$, increased from a mere $6 \mathrm{Mm}^{3}$ in 1961. Figure 2 shows the levels of accumulated storage dam capacity (in $\mathrm{Mm}^{3}$ ) vs. the inflow of water to the dams illustrating the great difference in amounts over the corresponding hydrological years. 
In 2008, Cyprus faced one of the most acute and prolonged droughts (a fourth consecutive drought year) with the winter season being extremely dry and the inflow to the reservoirs being approximately only $19 \mathrm{Mm}^{3}$. Water reserves of underground aquifers were drastically reduced and the water storage in the dams had reached dangerously low levels. This alarming depletion of water inflow to the dams for this period of time can easily be seen in Figure 2. Fortunately, the hydro-meteorological conditions for the successive years have been relatively good resulting in an improvement of the water resources in Cyprus. Over the last two years, the average annual rainfall values are numerically higher than the mean annual precipitation value (497 mm) considered from 1960 to 2013 (represented as a dotted straight line in Figure 2) and, indicative of these good rainfall years, is the increase of water inflow to the dams.

Figure 1. (a) Population (in thousands) diagram from 1961 to 2013; (b) Annual Precipitation in Cyprus (mm) for the corresponding years (Source: Cystat [18] and WDD statistics [23]).

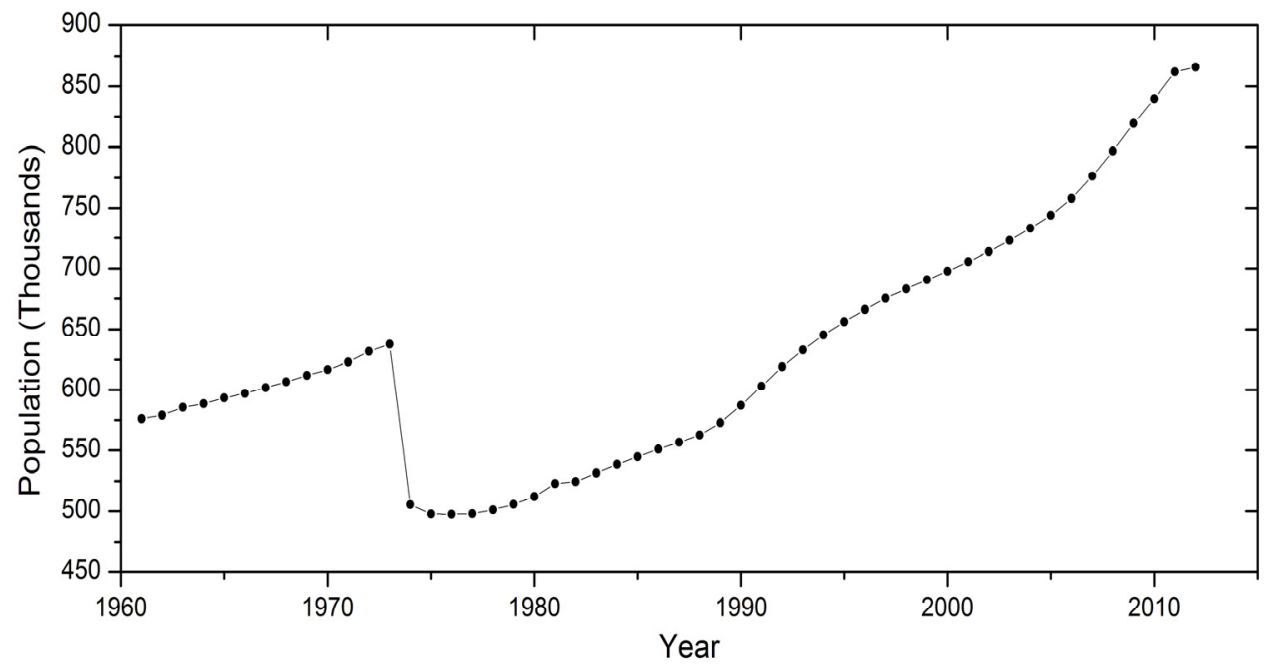

(a)

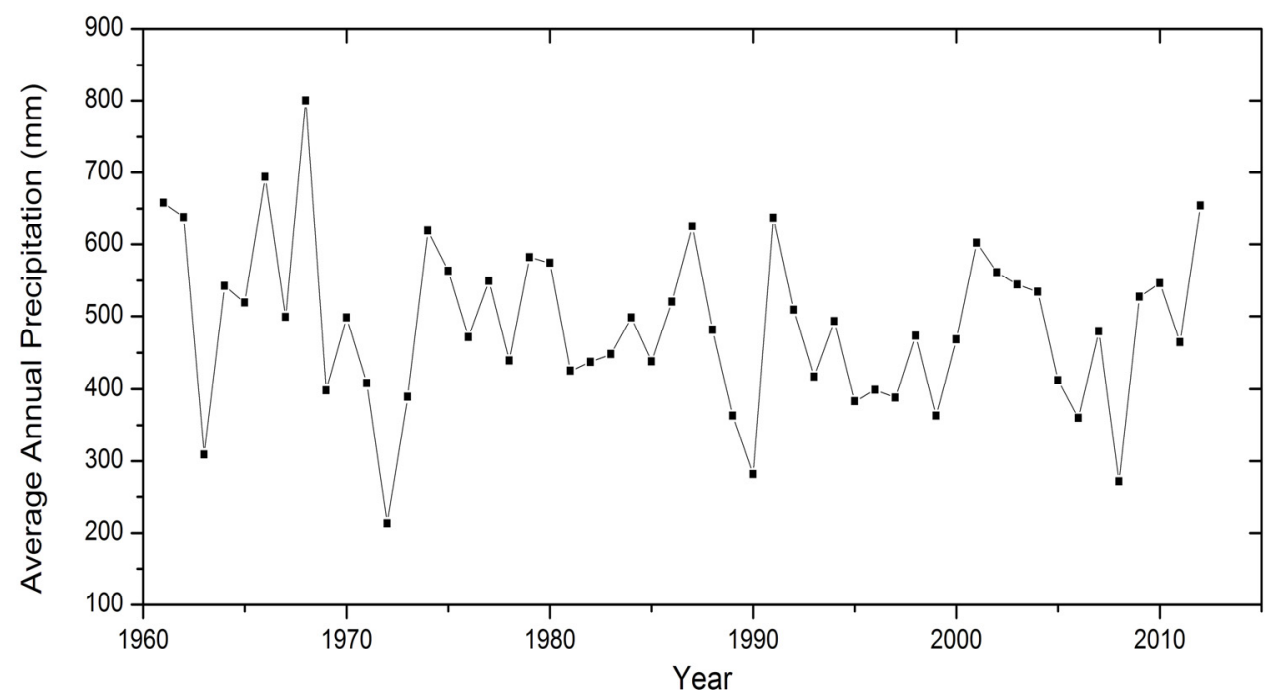

(b) 
Figure 2. Inflow of Water to the Dams (a) vs. Accumulated Storage Dam Capacity (b) (both in $\mathrm{Mm}^{3}$ ) and Average precipitation for the years 1960-2013 (c) (Data: [23,26]).

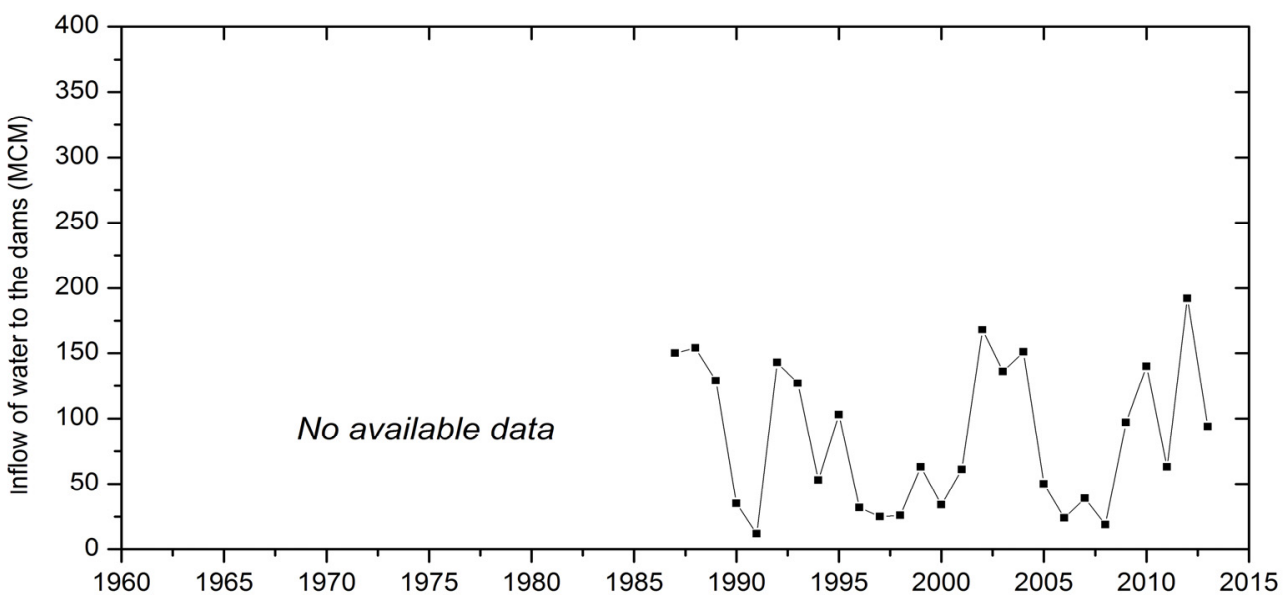

(a)

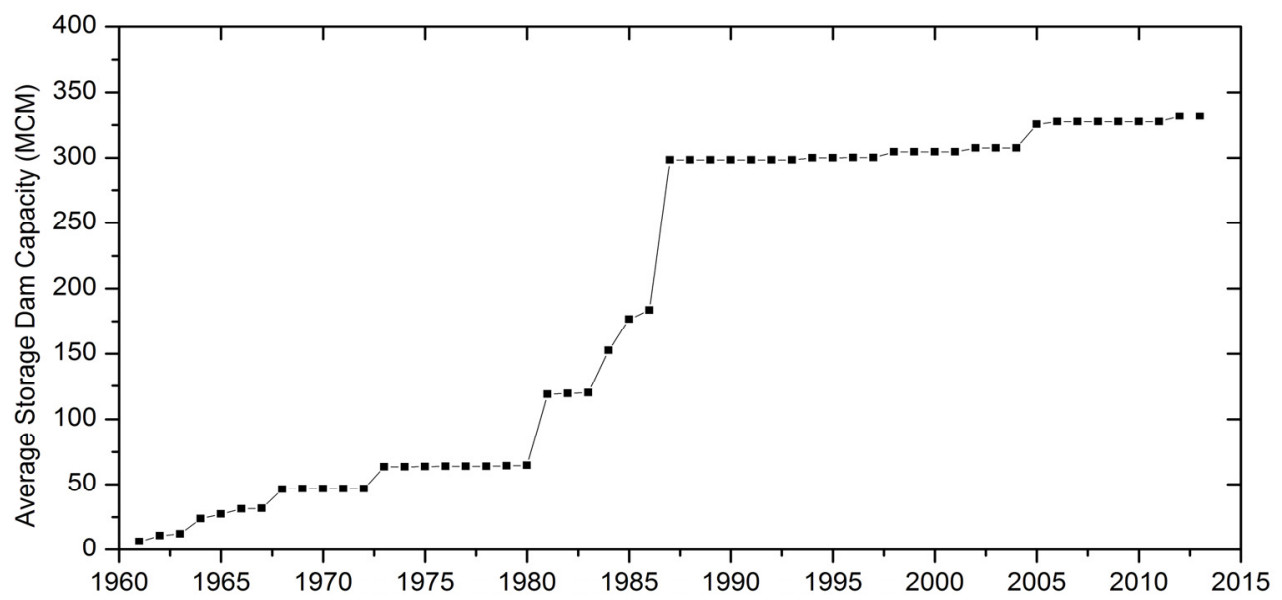

(b)

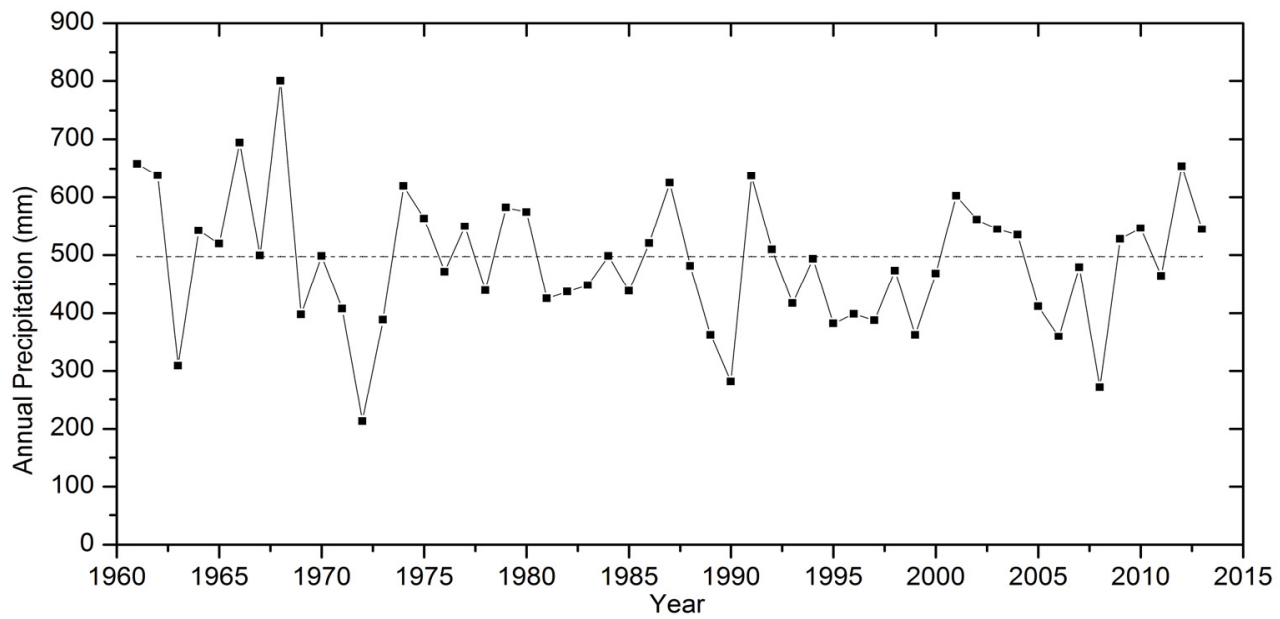

(c) 
In Cyprus, the appearance of low rainfall periods is a rule and not an exception. Subsequently, these critical periods have to be faced with readiness and without causing deficits to the islands water systems. One way to achieve this is by storing and wisely managing the reserves so as to accommodate for the low rain seasons.

Climate change models project more frequent and intense summer droughts in the years to come, due to a joint effect of a rise in temperature and a drop in precipitation particularly in the southern part of Europe [27]. In many cases, climatic global warming will increase the frequencies of drought occurrences, as well as those of floods, thus, aggravating the situation [28]. Climate change is projected to reduce water resources in many small islands, and for the case of Cyprus, a decline in rainfall may lead to a reduction in surface run-off $[29,30]$. Furthermore, Cyprus also has small catchments that do not provide any perennial flow. Therefore, the impacts of climate change and population growth will both worsen the water resource conditions of Cyprus.

\subsection{Water Stress and Scarcity}

Dry rivers and overexploited aquifers are signs for water stress which occurs when the demand for water exceeds the amount of accessible water or when the quality of the water is poor so that its usage is restricted. The water stress index (WSI) is an indicator that quantifies the extent of water scarcity in a country or a region at national level. A country's water stress is not only determined by the water availability but also by its water use and the index is defined as the ratio of annual water withdrawal from ground and surface water to the total renewable freshwater resources. Hence, high water stress indices can either be caused by low availability or excessive high water demand. This indicator is calculated at national level, on the basis of Eurostat information provided by the Member States of the European Union.

Figure 3 shows that Cyprus is the most affected country of the European Union, with a water stress index of approximately $66 \%[5,6,25]$. The OECD (2003) defines a water stress index of more than $40 \%$ as high water stress, $20 \%-40 \%$ is classified as medium-high, whilst $10 \%-20 \%$ is characterised as moderate water stress. Figure 3 demonstrates these corresponding classifications of water stress indices using assorted colours for each respective country, where, most importantly, the red coloured bars reflect high water stressed countries (note that another small island, Malta is not far behind Cyprus).

Worldwide, the number of inhabitants who reside in the high water stress index countries is in the range of 130 million equivalent to essentially the total population of the EU Mediterranean states (and $27 \%$ of the whole EU population). As expected, countries with higher water stress index are more conscious of the need to reclaim water, diminish water resource exploitation and perform advancements in implementing law and project development on water related issues. For instance, ten years ago Belgium had a high water stress rating, partially caused by low levels of sewage treatment (around 38\%), but following government action this has now improved (now 70\%) with thoughts now turning to re-use of water and the recycling of industrial water [6].

For the case of Cyprus, the high water stress index can be explained by the exploitation of the islands water resources, the diminishing volume of both groundwater and surface water storage, which leads to 
shorter retention times followed by deterioration of water quality due to pollution. For instance, in 1991, 36.3 Million Cubic Metres (MCM) of water was exploited (34\% of this came from dams and 66\% from abstraction sources such as boreholes), in 1997, the year desalination of sea water was first introduced on the island on a large scale basis, $44.8 \mathrm{MCM}$ of water was exploited (45\% came from dams, $43 \%$ from abstraction sources and 12\% from recycled water sources via desalination plants), and in 2005 water exploitation reached $73.3 \mathrm{MCM}$ (35\% came from dams, 23\% from abstraction and $42 \%$ from recycled water sources). In 2008, the year of the severe drought, the total water exploitation was $62.5 \mathrm{MCM}$ of which $24 \%$ came from dams, $19 \%$ from abstraction sources, $52 \%$ from desalination plants and 5\% from transported water sources. In 2013, the domestic supply of water sources was $77.5 \mathrm{MCM}$, of which $76 \%$ came from dams, $10 \%$ from abstraction sources and 14\% from desalination plants [23]. These figures demonstrate the evolution of Cyprus water sources exploitation illustrating that reclaimed water is an essential source for this country.

Figure 3. Water Stress index for European countries (Source: [5]).

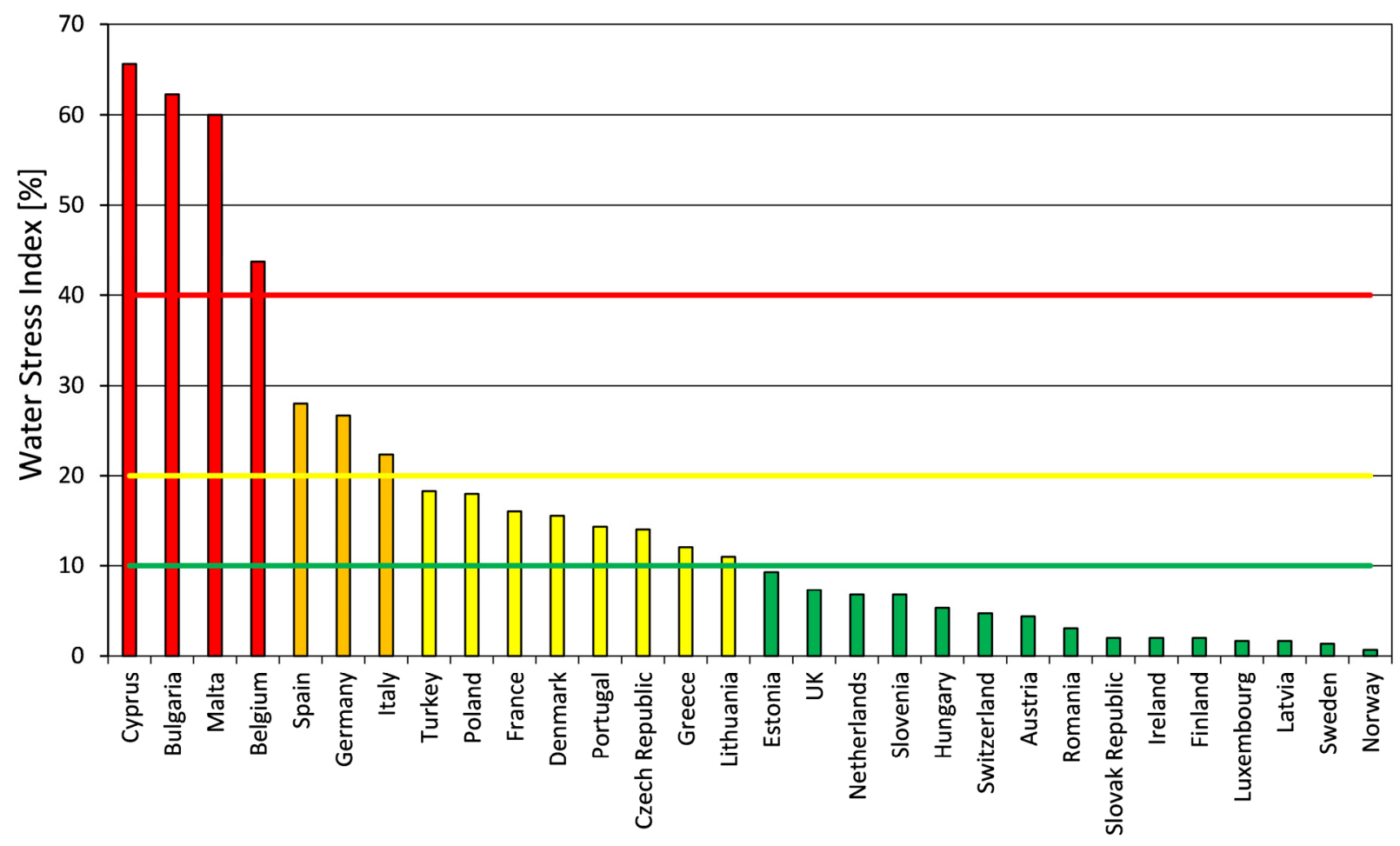

\section{Water Demand}

Domestic and irrigation are the two main sectors of water demand in Cyprus. Water demand is characterised by a pronounced seasonal peak in summer and is related to agricultural irrigation and tourist activities. Based upon the latest data from the Water Development Department, [15], the total annual water demand in the Government controlled areas is $275 \mathrm{Mm}^{3}$ per year, of which the dominated water use sector is agriculture and as noted earlier, in Section 2, accounts for $64 \%$ of the water demand needs of the 
island. Domestic water supply to households consumes $28.4 \%, 4.7 \%$ corresponds to the touristic and hotel water demands and industrial suppliers make up the $2.9 \%$ water demands.

Figures 4 and 5 illustrate the water demand distribution by sector and by source used respectively (whether this is groundwater: "aquifers", "boreholes", surface water: "dams" or using desalination water resources).

Figure 4. Diagram representation for water demand by sector: Agriculture, Domestic, Industry and Tourism Demand (Data: WDD statistics [15] and Cystat [31]).

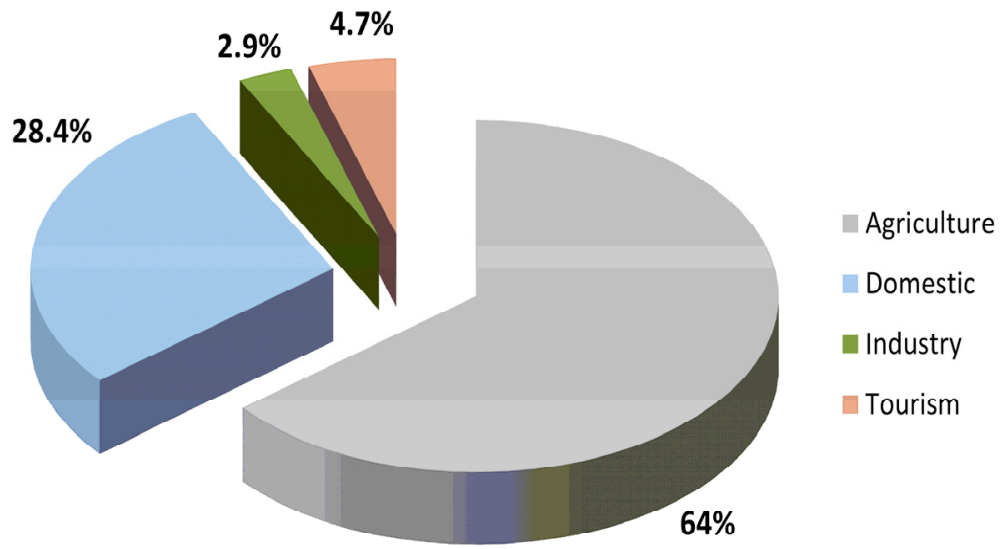

Figure 5. Water Demand by sector and sources used for the year 2006 (Data: WDD statistics [32]).

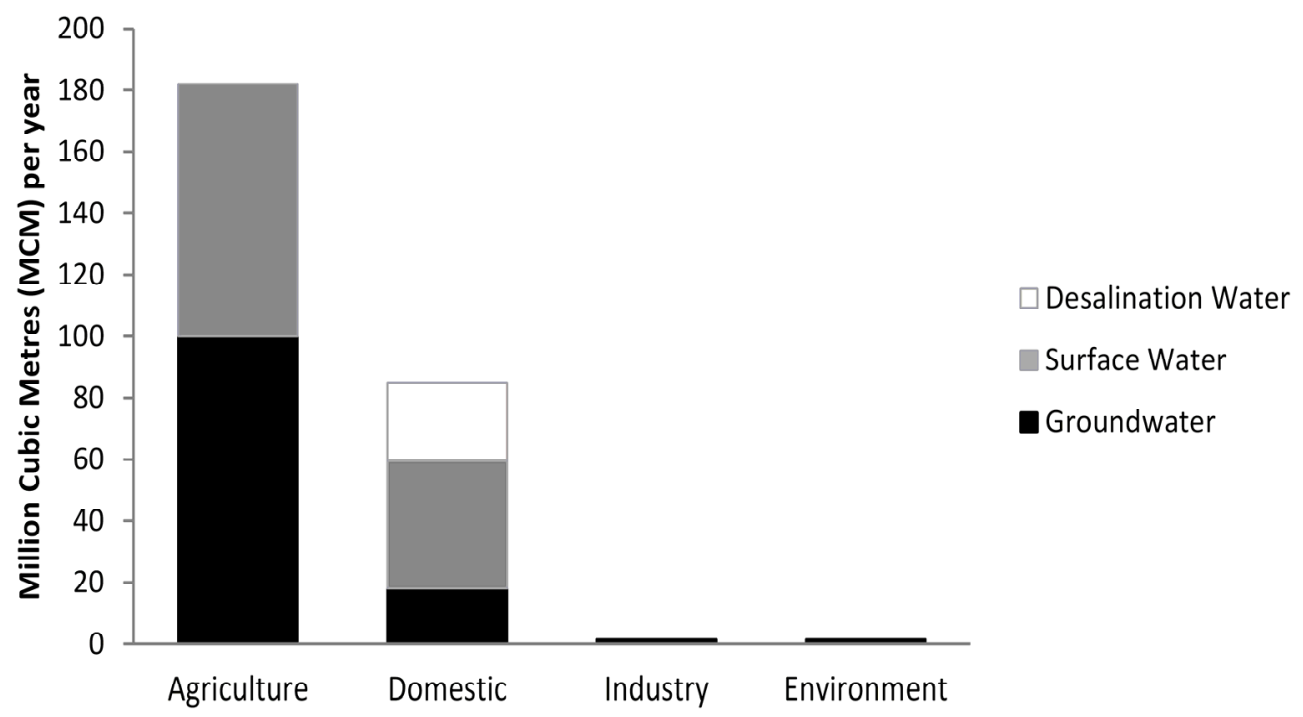

\subsection{Sources of Water Supply}

"Groundwater", that is water located beneath the earth's surface, is reliable and cheap when compared to other water sources. However, in Cyprus most aquifers are today exploited beyond their safe yield [29], estimated today at $110 \mathrm{Mm}^{3}$. The excess pumping over natural recharge is in the order of $29 \mathrm{Mm}^{3}$ per year [22,33]. For sustainable aquifer management and protection of groundwater resources, it is 
estimated that extraction from all aquifers should not exceed $81.3 \mathrm{Mm}^{3}$ per year [23,34]. It is, thus, obvious from these numbers that reduction of the extraction is needed. The existing conditions have resulted in saline water intrusion and consequent quality deterioration in coastal aquifers and depletion of inland aquifers. Saline water intrusion in aquifers leads to the withdrawal of treasured underground water storage reservoirs. Annual groundwater balance of Cyprus averaged over the period 1991-2000, show that sea intrusion amounted to $12.8 \mathrm{Mm}^{3}$ [33,34]. There are many examples of overpumping and seawater intrusion in coastal aquifers. Typical ones are; the aquifers of Morfou, Kokkinohoria, Kiti-Pervolia, and Akrotiri [34]. Records from 2005 show that $89 \%$ of the groundwater bodies are at risk due to over pumping and $63 \%$ are at risk due to sea-water intrusion [35]. This then places the emphasis on the dams. The predicament now is that given the decline in precipitation these reservoirs seem oversized and do not yield sufficient water. Ironically, a boost in storage capacity during the 1980 s coincided with a drop in average annual precipitation, as illustrated in Figure 2.

In the Middle East, where the economies are more buoyant, desalination of sea water is seen as the answer to water scarcity. In Europe, Spain is the largest user of desalination technologies. Other Mediterranean countries, such as Greece, Italy, Malta and Portugal, also rely increasingly on desalinated water as an additional resource for public water supply and to support holiday resorts in arid areas. Malta, for example, relies on desalination for $57 \%$ of its water supply. In Cyprus, desalination on a large-scale basis was introduced in 1997 with the operation of the $20,000 \mathrm{~m}^{3}$ per day, reverse osmosis plant at Dhekelia. Due to the drought prevailing at the time, the plant was soon expanded to $40,000 \mathrm{~m}^{3}$ per day. The plant operates on a Build-Own-Operate-Transfer (BOOT) basis and the desalinated water is presently sold to the Government. The Cypriot Department of Water Development (WDD) proceeded with the construction of another desalination plant in Larnaka and a mobile desalination unit in the Limassol district, to minimise the dependence on weather conditions and secure the sufficient potable water. Future plans include the construction of another desalination plant near Limassol and to for mobile units that are installed on ships that cruise the Cypriot coastline and supply freshwater to municipalities where needed (WDD Tender).

Figure 6, depicts with the aid of bar charts, the amount in Million Cubic Metres (MCM) of water that desalination plants and dams respectively contribute to the government water works for domestic water supply purposes. From the year of first introduction 1997 until 2007, desalination counted for about 40\% of the total domestic water supply, with a clear upward trend then after until 2011. The last three years show an evident decline for the domestic water supply source using desalination plants. More specifically in 2009 for instance, the domestic water demand for the government water works accumulated to 70.3 MCM, of which desalination contributed to 49.4 MCM per year [23]. Therefore, the desalination plants contribute to the Water Balance $70 \%$ of the total domestic water. In 2013, a different picture is visible, where only $14 \%$ of the total domestic water comes from desalination [36]. This drop in domestic demand for water contributed by desalination plants was interchanged by an increase in the domestic water demand coming from dams. This increase was a product of the decision to operate desalination plants at their lowest possible production capacity while most of the plants were also set in standby mode. The desalination plants in Larnaka and Dhekelia were instructed to reduce production, while other plants, 
such as the Limassol and Vassilikos Desalination plants are currently set in standby mode [23]. These instructions were according to contractual provisions, which allow the Water Development Department to manage the water production taking into account the water reserves [23]. Additionally, after 2011, following the disastrous explosion at Mari Naval Base all desalination plants then after were operating on reduced power load savings.

Figure 6. Amount in Million Cubic Metres (MCM) of water that desalination plants (a) and dams (b) respectively contribute to the government water works for domestic water supply purposes (Data: [36]).

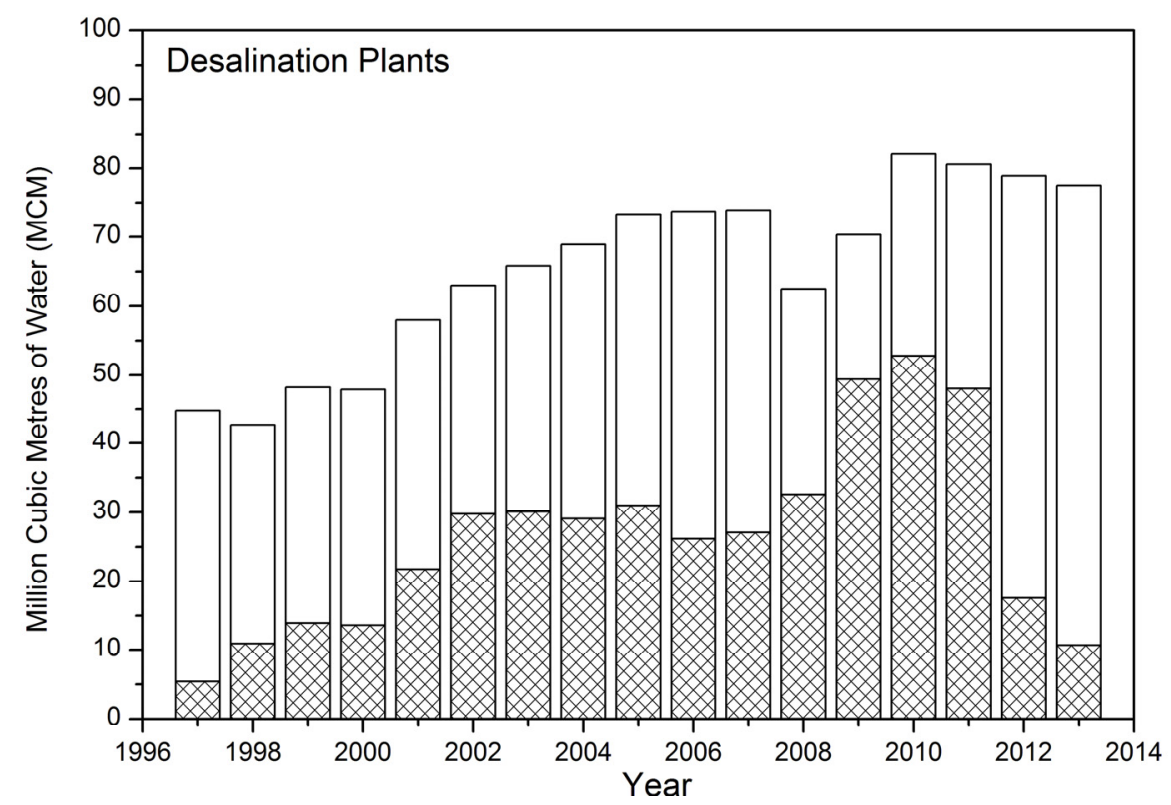

(a)

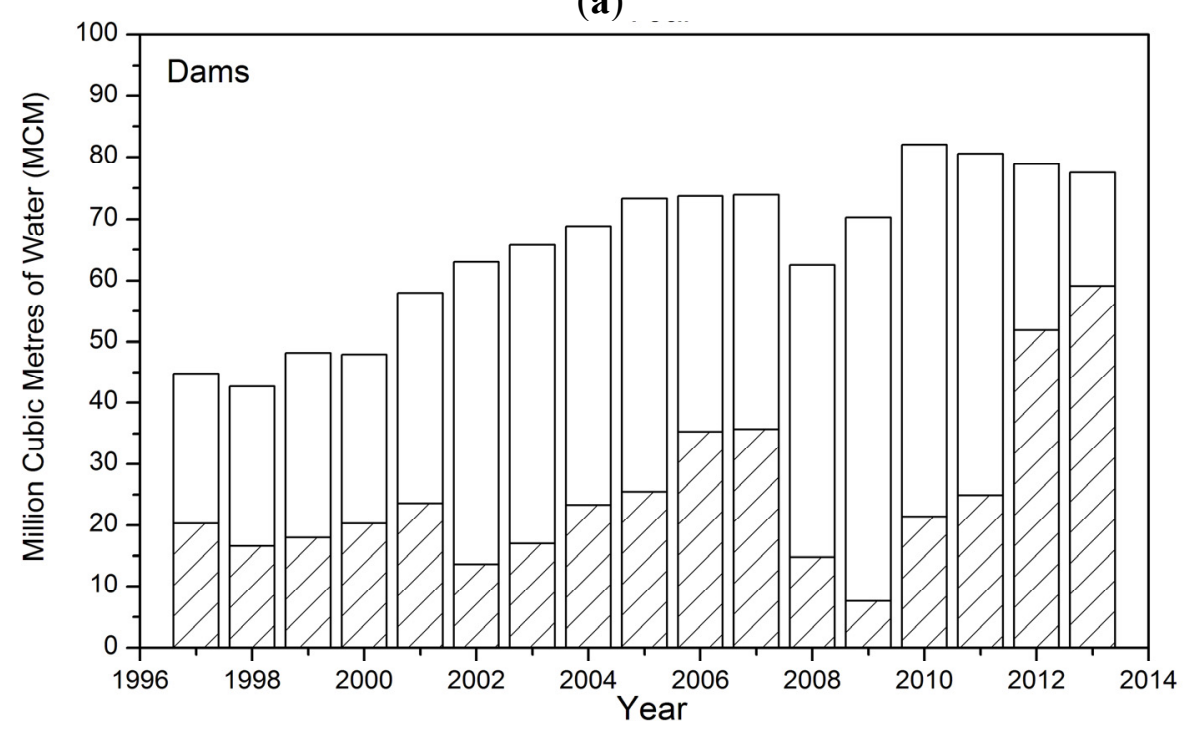

(b) 
The first ever combined solar power and desalination plant will be constructed in Cyprus, following the recent success of a research project carried out by the Cyprus Institute in collaboration with Massachusetts Institute of Technology, University of Illinois and the Electricity Authority of Cyprus [37]. The proposed system is innovative introducing solar powered desalination units for the production of water and simultaneous production of economically competitive, green energy.

Despite the environmental impact, mainly the emission of greenhouse gasses which should not leave us indifferent (the power consumed by the desalination plants generates an additional 571.72 ton of $\mathrm{CO}_{2}$ per year [38]) and the financial costs, compromising of production costs which is not usually recovered especially at times where the oil price is unstable, it seems that desalination remains the only means of achieving water security for domestic water leaving the less reliable dam water for other uses. Even under the assumption of a rapid increase in water demand, and despite climate change, calculations have been made to demonstrate that desalination in Cyprus can most likely satisfy the water demand of households, industry and tourism until 2030 [13].

As a result of the decrease of the water stored in the dams and the significant reduction of water reserves in general during the years 2007-2008, it became imperative to impose severe restrictions in the supply of water to households and farmers and to implement costly measures for securing the absolutely necessary quantity of potable water. More specifically, in April 2008, an agreement was signed for the conveyance of $8 \mathrm{Mm}^{3}$ of water from Greece to Cyprus, at a cost of $€ 35$ million (transportation cost only) an additional $€ 4.4$ million to pay for the cost of water and the necessary infrastructure at the port of Limassol amounted to another $€ 1.6$ million, clearly not a viable repeatable. In fact, the total cost of the imported water per $\mathrm{Mm}^{3}\left(5.125 € / \mathrm{Mm}^{3}\right)$ was approximately five times more than the total cost of the

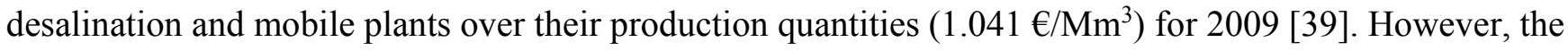
unprecedented action of water transportation was vital to supply Limassol with drinking water and marked the extraordinary severity of the drought.

Most of the sewage in Cyprus, around 90\%, is treated in municipal wastewater treatment plants $[18,30]$, while a number of smaller communities and decentralised plants for military camps, hotels and hospitals contribute a minor share. Treatment mostly consists of secondary treatment, which aims to reduce organic loads. Nutrient removal is only applied to one third of wastewater treatment facilities. Effluent undergoes sand filtration and chlorination before being reused. Most treated wastewater is used directly for irrigation. More specifically, to date, in Cyprus approximately $72 \%$ of treated effluent is reused for irrigation purposes; for tree crops, seasonal and permanent crops, no leafy vegetables (e.g., tomatoes, potatoes, peppers, etc.) and green areas. On average $15 \%$ of treated effluent is used for the enrichment of underground water. Due to seasonal demand of water for irrigation and limited storage capacity, certain amounts of treated effluent are discharged to the sea (about 10\%) and Polemidia Dam (non-potable), during the winter months [30].

The potential for recycled water depends on the availability and accessibility of wastewater, hence, the wastewater infrastructure becomes a critical factor as does the acceptance by potential end users and consumers. 
"Recycled water" provides an additional drought proof water supply. The use of recycled water has mostly focused on irrigation, to contest the overdependence of agriculture on groundwater [29]. Trees are the most irrigated crops, such as citrus and olive trees but also cow grass. Furthermore, environmental benefits could be attained by using recycled water to recharge depleted aquifers and reduce sea-water intrusion while avoiding the ecological costs of discarding wastewater in the sea [40]. This is the method used in Paphos, where the Ezousa aquifer is recharged artificially with $2-3 \mathrm{Mm}^{3}$ reclaimed effluent per year, which is re-abstracted for irrigation [25]. In addition, most recently, the Cyprus Water Development Department focused on using the rapidly depleting Akrotiri aquifer as a storage tank, in other words to recharge the aquifer with treated wastewater in order to reduce the effects of sea intrusion. Generally, recycled water for irrigation and recharge purposes is a growing resource in Cyprus.

"Grey water" is a means of reducing the consumption of water in households, other living quarters such as hotels and a few types of industry such as laundries. In households, it may reduce water consumption by 50 per cent. Water, which is used for washing (wash-hand basins, baths, showers, clothes washing machines and dishwashers, but not kitchen sink or toilets), is collected in a separate system. This "grey" water, so called because of its cloudy aspect, can be used for toilet flushing and for domestic irrigation, after filtration. In Cyprus, this form of water reuse is spreading, as its benefits make it an attractive investment for households or other organisations. The Government of Cyprus has set up a subsidising programme for grey water reuse at household level [23]. In 2010, the subsidy was $€ 3000$ per plant and covered half the cost (WDD website). In 2011, installation and maintenance of grey water recycling systems materialized in further 49 schools [23]. Subsidies have been prioritsed but due to the current financial and economic situation of the island, it may take time for these to now to be taken up.

In the tourism sector, towel reuse and linen change policies are now fairly common, and can save not only water, but energy and detergent too. The programmes are explained to guests by using a simple card. The guests can then decide when they would like their towels changed, rather than automatically changing them according to the regulations of the Cyprus Tourism Organisation [41]. Information cards and discreet signs politely remind customers to conserve water by not running the tap when cleaning their teeth or shaving. In a "typical" 100 room hotel, which adopts the two programmes of towel reuse and linen change, a reduction in laundry chemicals by $22 \%$ can be incurred and water and energy costs reduced by as much as $€ 5300$ a year [42]. Maintenance and labour costs are subsequently reduced with laundry equipment and linens lasting for longer period of time.

A proposition to the Water Development Department for further deliberation and testing could be to consider grey water combined with rain-water collection from the roof of a building. This will significantly reduce the cost of separate systems and will also have the advantage that the grey water would be diluted by the rain water, allowing the water in the toilets to be clear for much of the year.

The actual water allocation to agriculture is prepared through governmentally managed schemes and is dependent on availability and based upon a quota system. More specifically, farmers apply for their required volumes for the irrigation season at the beginning of the year and their main water sources are ground and surface water, received mostly by the dams. Private boreholes are also supposed to be 
exploited and since clearly these boreholes draw water from the same aquifers, they should be factored into models for water delivery.

Usually the water demand is more than the supply and so water needs, especially for irrigation, are rarely fully satisfied $[43,44]$. For example, since 1996, water demand for irrigated agriculture was satisfied only in 2004, when all the dams had over-spilled $\left(151 \mathrm{Mm}^{3}\right)$ due to adequate and long awaited for rainfall. (recall Figure 2). Based on the latest figures, total water demand in Cyprus accumulates to around $290 \mathrm{Mm}^{3}$ whereas the total water supply from the different sectors reaches around $262 \mathrm{Mm}^{3}[33,45]$.

Deficits of supply during droughts can be as high as $70 \%$ [46], causing considerable loss in agricultural production and income.

The domestic water supply is mainly served by surface water with desalination and pumped groundwater contributing to the rest of the water withdrawal. Industrial and Environmental demand are dependent mostly on groundwater. In total, the water demand pattern consists of mostly shares of ground and surface water with desalination satisfying a smaller portion of the total demand.

The use of surface water resources is managed by the Water Development Department, whilst the abstraction of ground water is less well administered. To date, the number of boreholes is estimated to exceed 100,000 [15], a considerable number of which are unlicensed and possibly illegal with uncontrolled abstraction. The conditions which are included in the licenses issued by the District officer for the opening of boreholes are inter alia, the installation of water meters, so as to control the quantity of water pumped, the specification of the maximum quantity of water that is permitted to be pumped annually and the purpose for which the pumped water can be used.

It is apparent though that with numerous unlicensed boreholes being opened annually and the pumping of water from the approved boreholes, that the supervision exercised by the district officers is very limited. The yearly abstraction of illegal boreholes is challenging to register. The abstraction is estimated indirectly through the size of the irrigated area and the types of crops irrigated. In the last fifteen years, abstraction has gradually increased and today most of the aquifers are over-pumped [35]. Recalling the results of the annual report of the Water Framework Directive [35], only two out of the nineteen groundwater bodies are not over pumped. As a result, due to the non-sustainable abstraction and in view of the general deterioration of the water reserves in Cyprus, it is vital that immediate measures are taken for ensuring that the owners of private boreholes comply fully with the terms of their license, especially with regard to the quantities of water pumped. Since the Integrated Water Management Law entered into force on 15 November 2010, during the year 2012 a step forward was achieved with warning letters being issued regarding compliance with the terms of borehole drilling and water abstraction permits and furthermore, 17 cases were taken to court [15].

The relevance of the different sectors for the Cypriot economy is illustrated in Figure 7. The Industrial (secondary) sector, which includes manufacturing, energy production and construction, produces roughly $19 \%$ of the gross domestic product and the total water demand share as abovementioned $1.5 \%$. The tertiary (service) sector contributes about $78 \%$ of the gross domestic product.

In 2006, the revenues of tourism amounted to 1755.3 million Euros, which represents $14 \%$ of the GDP for that particular year [47] and around 7\% of the total water demand share (latter percentage referring to 
hotels and tourism activities only [43]). The well established and expanding tourism industry of the island puts a strain on the water resources, especially during summer months, when they are at their most vulnerable period. Water demand for tourism is expected to increase further following the controversial legislation approved for the creation of golf courses. This is a highly disputed topic in view of the recent water crisis, though current licenses exist to allow for the construction of new golf courses under the provision that the irrigation and water supply of the project must be carried out by desalination plants that will use electric power from renewable sources of energy. In the framework of the implementation of the Government's policy for the development of golf courses, the Water Development Department is as a result obliged to provide considerable input in the environmental assessment procedure relating to each golf course development [15].

Figure 7. Demand share by sector and contribution to GDP for the year 2006 (Data: WDD statistics [32] and Cystat, 2009 [47]).

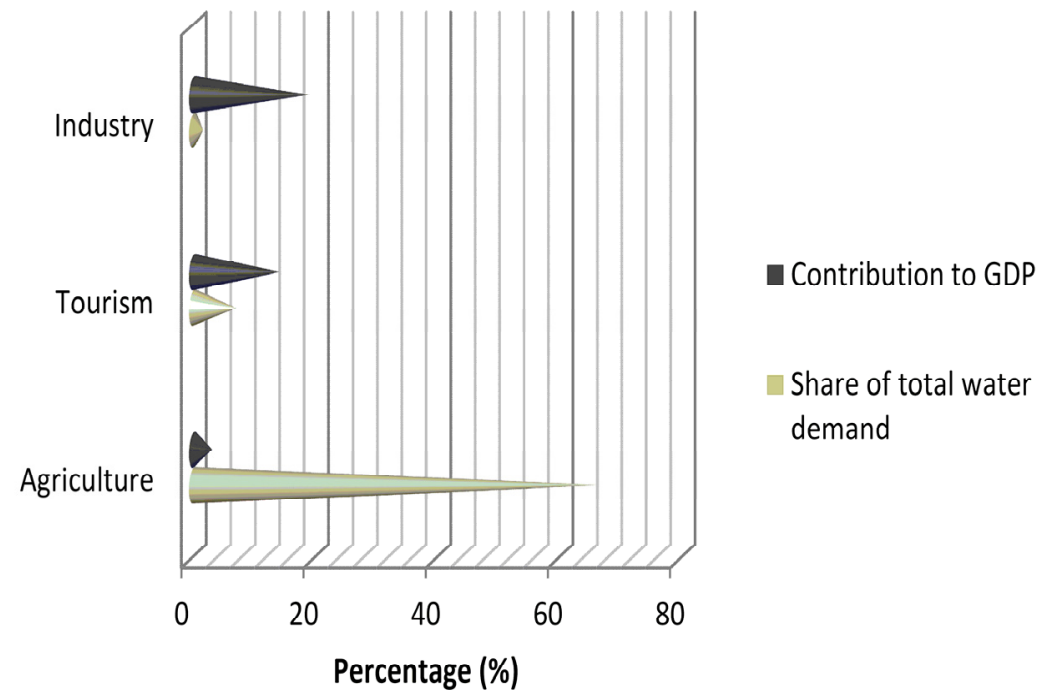

The striking imbalance of economic return on water input can be seen in the agricultural (primary) sector (see Figure 7). Agriculture accounts for $64 \%$ of the annual water demand with a measly contribution of 3\% to the country's economy. This ratio must then be considered with rationale when reassessments of water allocation and distribution measures are taken into action. Moreover, since the number one offender seems to be agriculture, where around two thirds of Cyprus' water is sucked-up by farms that grow often thirsty crops like citrus and potatoes that are sold outside the country, one must provide farmers with alternative crops that would per input of water provide more financial return, for instance the production of pomegranates. The future development of agriculture will be greatly dependent on the effects of climate change. Reduced availability of irrigation water and less nutrient uptake may cause reduction in yields. Other factors with negative impacts could be higher risk of heat stress, extreme events during development stages, higher risk of rainy days during sowing dates and so forth [48].

In terms of the governmental irrigating schemes, irrigation efficiency is high since modern irrigation systems have been used in Cyprus for the last 30 years. Drippers, mini sprinklers and low capacity 
sprinklers are used for irrigating greenhouse vegetables and flowers, trees and field vegetables. Proper hydraulic design of the irrigation systems, offered free of charge by the Ministry, coupled with a subsidy of the installation cost, result in a rapid expansion of the new irrigation methods.

The farmers have extensively adopted modern irrigation technology, which was introduced and continuously being tested by the Agricultural Research Institute in order to evaluate the different systems under local conditions and select appropriate methods for each cultivation [49]. It is estimated that, currently, over $95 \%$ of the total irrigated land of the country is being served by modern irrigation schemes.

Whilst irrigation technology is reasonably advanced in Cyprus, the irrigation programme does leave room for optimising the water usage. For instance changes in cropping pattern and generally in the type of crops produced, may offer potential for water saving in the agricultural sector. A concept that should be considered when discussing demand related to the hidden amount of water required to produce varied crops and goods. "Virtual Water" is the volume of water used in the production process of a commodity (good or service) as devised by Allan [50] when he sought an alternative solution to the acute water scarcity problems of the Middle East. The term refers to the amount of water in a product, not in its real sense but in its virtual sense, whereby the virtual metaphor refers to the invisible or evaporated water that is required during the production process of a certain product, measured at the place of production. The fundamental principle of Allan's elaboration on virtual water is that it is much more preferable for water scarce countries to import virtual water via food products rather than using the limited domestic water resources for their production [7,14,51]. This is called "Virtual Water Trade" and it allows relief to high water stressed countries.

This virtual trade concept can be better justified by considering an example from Zoumides' recent virtual crop studies of Cyprus [14]. Cyprus utilises barley both from domestic and foreign origin. However the virtual water content of one ton of barley produced within Cyprus is $2237 \mathrm{~m}^{3}$ whereas the same quantity of imported barely from Ukraine requires only $713 \mathrm{~m}^{3}$. Thus, the country saves water by importing rather than producing all the required barley quantity itself.

Therefore, water savings endured due to a virtual water trade can in turn be used to produce alternative, higher value agricultural crops, support environmental services and serve growing domestic needs.

The outcomes of recent studies of virtual water on crop products in Cyprus show that overall around $20 \%$ of the total Cypriot agricultural water use ends up in foreign markets in the form of virtual water embedded in crop products [14,52]. Since the agricultural sector is the biggest consumer of water, it is indeed striking that a water scarce country like Cyprus exports about a third of the total agricultural water used [53]. Specifically, Cyprus exports around $215 \mathrm{Mm}^{3}$ of virtual water embedded in crop products, such as fruits (primarily citrus), dairy products, vegetables and potatoes, when the total agricultural water usage is $629 \mathrm{Mm}^{3}$ [53].

This raises the questions on the allocation of irrigation water and the current cropping patterns in Cyprus and is something that should be considered by policy makers. A different cropping matrix is necessary based primarily on the water criteria of crops and considering the climatic conditions and the diminishing water availability of the country. Crop shift and water allocation are two options in any water agricultural saving policy. Specific data are needed firstly for each agricultural land to enable achieving 
best choices that limits external and internal migration and upholds the country's food security. With this in mind, the first step should be further research including a complete profile for each agricultural land, covering points such as source of the water for irrigation, destination of the agricultural products, if exported or locally consumed, the suitability of the land for alternative crops and the potential markets for the new ones, and the suitability of the land for other investments like tourism [45].

Shifting to a low water consuming economy within the agricultural sector can be achieved by choosing strategies that adopt agronomical research and address the diversity and suitability of crops. For the farmer however, shifting crop patterns might be considered risky due to their existing supply chain networks, the time lags that exist between the production of the new crop and the fear of acceptance by the market. Principally for small scale farming, targeted marketing can focus on improving crop planning by promoting the cultivation of high added value and low water consuming products. Apart from improving water use efficiency, such measures will also improve the role of farmers and rural population in shielding environmental resources [52].

\subsection{Water Quality}

The pollution of water supplies reduces the availability of clean water for usage. This is particularly severe during times of water shortages. As water becomes scarce, rivers and streams become increasingly sensitive to the effects of pollution, as do those human and other living organisms, which depend on the water.

Water quality problems in Cyprus are due to the presence of salts and pollution exacerbated by agriculture. High salt concentrations are becoming increasingly present in groundwater due to the over pumping and subsequent salt water intrusion into the aquifer [23]. Recent studies have shown that reservoir water (surface water stored in dams) is becoming increasingly polluted with chlorinated pesticides, reaching levels that are higher than the permissible amounts set by the European Union [54].

Approximately a quarter of the groundwater bodies in Cyprus are at risk due to excessive nitrate concentrations, from urbanisation (waste water in septic tanks and cesspools) and agricultural activities [41]. Water from wells is, however, free of pesticide residues, although higher than acceptable levels of nitrates are common in areas that are intensively farmed [54].

Qualitative monitoring of water resources continue to date, as in accordance with Article 8 of the Water Framework Directive 2000/60/EC as well monitoring of the implementation of national groundwater monitoring programmes [36]. As part of these programmes, in 2013, the following resources were systematically monitored: 46 points on rivers, 13 reservoirs, 88 boreholes as part of the Water Framework Directive monitoring programme and 44 boreholes as part of the national groundwater monitoring programme. All quantitative and qualitative monitoring results are imported into the Department's Hydrogeological database (CYMOS) and submitted to the Eionet-WISE network of the European Environment Agency [36].

The latest chemical analyses (for 2013) for potable water quality from boreholes and springs (estimated to 500) used by communities show more than 71 exceedances of parameter values, specified in accordance to the Directive 1983/98/EC [36]. In cases were the exceedances occurred on the single water 
supply source of a community, relevant authorities were informed by telephone within $24 \mathrm{~h}$ from the notification of the results whereas in other cases (more than one source of water supply) the relevant authorities were notified about the exceedances in writing [36].

\section{Institutional Framework}

The Water Development Department is responsible for implementing the water policy of the Ministry of Agriculture, Natural Resources and Environment with the objective of enhancing the national development and sustainable management of the water resources in Cyprus.

Previous years saw the water management in Cyprus being undertaken by numerous organisations and authorities; such as the Ministry of Health, responsible for controlling the drinking and water bathing quality, the Ministry of Agriculture, liable for the education of farmers in all matters concerning the agricultural production [55], the Ministry of Interior, accountable for the authorisation of most water use such as abstraction from boreholes, the District Water Boards, responsible for the water distribution to domestic and industrial final end users, the House of Parliament, accountable for approving the consumer prices and the District Sewage Boards, responsible for the task of wastewater collection, operation, and maintenance of the main sewers system.

However, in order to ensure sustainability of the water sector of the island, it only seems reasonable that all water resources come under one, single organisational framework. Therefore, the Government planned to reorganise the institutional groups of the water sector through the establishment of a single water entity without affecting the water users and water supplier relationship. On 15 November 2010, the Integrated Water Management Law (79(1)/2010) [23] was enforced which opened new horizons and presented simultaneously new challenges for the Water Development Department. According to the Law, the integrated management of water is assigned only to the Water Development department, in the framework of the Government general Water Policy, as determined by the Council of Ministers.

The approval of this law by the Parliament of Cyprus, constitutes to a historical achievement, as it now addresses the issue of previous fragmented responsibilities and authorities regarding water management amongst the various departments, which resulted in wasteful resources and ultimately in the incapability to exercise an integrated, coherent and effective management of all water resources.

For instance, in accordance with the Law, all controls relating to water management that were previously implemented by the district officers and the department of Town Planning and Housing, such as borehole drilling and groundwater abstraction permits, are now transferred to the Water Development Department.

The department currently covers areas such as collection, processing, recording of hydrological, hydrogeological, geotechnical data (all necessary for the improvement and protection of the qualitative and quantitative rating of surface and groundwater bodies) construction of feasibility studies, design, implementation, operation and maintenance of dams, ponds, irrigation, water supply and sewerage networks, wastewater treatment and desalination plants, as well as creating awareness of water saving techniques amongst customers [15]. 


\section{Water Framework Directive}

The immense importance of water is definitely a worldwide belief. The extensive lack of water, the ongoing deterioration and degradation as well as the hazardous increase of pollution on water resources for supply and irrigation in many parts of the world is now a serious and existent threat to humanity. Provided that there is a continuation and increasing pressure on water resources, it is important to have effective organisations and measures that address the problems and help to secure these resources for the present and future generations.

The European Union, aware of the importance of protecting and conserving the aquatic environment in the community devised a new Framework Directive establishing the basic principles of sustainable water policy in the European Union. With the accession of Cyprus into the EU, the island must comply fully with the requirements of this Directive, for the proper management and protection of this precious resource. The main objective being to prevent further deterioration of all waters and to achieve "good" qualitative and quantitative in ground water status and good ecological and chemical status in surface water by 2015 .

A significant aim of the Directive that must be highlighted are to protect all rivers, lakes, coastal waters and groundwater, to certify reduction and control of pollution from all sources including agriculture, industry activity and to ensure the implementation of the "polluter pays" "principle" in water pricing policies. By the end of 2011, prices did increase considerably, due to Cyprus' obligation to comply with the European Water Framework Directive.

The Water Development Department continues yearly to implement national groundwater monitoring programs in accordance to the Water Framework Directive. The monitoring of the quality of potable water from boreholes and springs continues and, for example, in 2012, following the chemical analysis of the potable water quality, more than 40 cases were identified when the parameter values were exceeded and relevant authorities were directly informed [15].

Hence, the effects of implementing this directive in Cyprus can only bring about positive outcomes and the successful functioning of the aforesaid directive will create the necessary conditions to support a policy that will result in satisfactory and effective protection, as well as a rational management and utilization of the valuable water resources. It presupposes though, political will, long term planning, change of attitude towards water and an active involvement of the society. Some challenges and shortcomings of the directive are the lack of sufficient quantitative and qualitative data, the lack of a national network of data collection and storing [56]. Even though Cyprus is characterised as one river basin, the government of Cyprus cannot exercise control over $40 \%$ of the area. The shortage of expertise, lack of experience in consultation processes and the attitude of the users towards water and generally the environment can also be considered as issues that Cyprus faces during the adoption of this directive.

\section{Water Management}

In response to the acute recent droughts in Cyprus, a series of measures to manage users' demand were encouraged and adopted by the Government. Such management measures include water rationing, 
increase of public awareness for water conservation methods and water pricing for improvement of water use efficiency and water saving. The drastic tool to reduce water consumption by restricting the water supply has been extensively applied in an attempt to curtail the demand in periods of draught. The Water Development Department is urged to impose water cuts, which force the corresponding authorities to interrupt the supply periodically for domestic purposes and to ration the water for agriculture below the agreed amounts.

For the domestic sector, these water interruptions have directed people to get along and cope with less available water however at the price of inconvenience. Water cuts have driven behavioural changes in households so that domestic water users have altered the timing of their cleaning habits in order to match the hours of supply. For instance some water preservation behavioural changes are checking the plumbing installation for leaks, taking a shower instead of a bath, avoid running water until it is hot, turning off the shower water while soap is applied to body, washing only full loads in the washing and dishwashing machines, watering the garden early in the morning or late in the evening when evaporation is limited, washing the car with a sponge and a bucket instead of a hosepipe, which is, anyhow, prohibited by Law and others.

In 2008 the domestic supply of water decreased by $15 \%$, more particularly from $74 \mathrm{Mm}^{3}$ in previous years to $62 \mathrm{Mm}^{3}$ [57]. The strict restrictions on water supply to households meant that people were receiving water only 36 hours per week. Thus, in an encouraging way, water rationing has proven that water consumption can be reduced if the pressure is sufficiently high. This of course is a loss of independence and freedom [58]. It is worth adding here that the restriction on water rationing had only been lifted in February 2010, because of primarily improved precipitation conditions.

Other water conservation measures include subsidies for technical installations, such as hot water recirculators, connection of boreholes with lavatories, installation of grey water treatment plants for household and home garden irrigation purposes.

Furthermore, the campaign for raising the water awareness of the public towards water conservation has proven to be successful. The Water Development Department has attempted to hoist citizen consciousness through seminars, lectures, advertisements in all types of media, flyers delivered to each home and by employing philologists in each district on a daily basis to inform children in primary schools and nurseries about water saving techniques and the severity of water scarcity on the island. The goal is the cultivation of the water consciousness from a young age. During 2012, around 50 lectures were given to elementary and secondary students attended by 10,000 pupils and at military camps in order to promote a water saving culture and an efficient usage of water [15,39]. To highlight, these activities have a double purpose: the immediate goal is to pass the ways of saving water in homes and the long term goal is the gradual change in the mentality of tomorrow citizens concerning the correct use of water. People should be motivated to always use water rationally and be able to take informed decisions on smart water saving options.

Water pricing is the most visible sign for its valuation and an appropriate way to manage demand. The price of water should reflect the scarcity of this precious form of goods with the aim of preventing its wasteful use. In some governmental water projects, water prices doubled but still kept at affordable levels. 
Based on recent data, prices for non-agricultural use (e.g., green areas, play courses) are considerably higher, where charges for irrigated water usage (fresh water from dams) in agriculture is set at 17 cents per $\mathrm{m}^{3}$, green areas at $34 \mathrm{c} / \mathrm{m}^{3}$ and overconsumption charges at $56 \mathrm{c} / \mathrm{m}^{3}$. Irrigation water from Tertiary Treatment is set at $7 \mathrm{c} / \mathrm{m}^{3}$ for agriculture and $15 \mathrm{c} / \mathrm{m}^{3}$ for green areas [15].

A recent briefing paper commissioned by the Cyprus Water Development Department projects price increases of between 25 and 165 per cent, depending on which a pricing model (a flat rate model being applied across the island or a scenario of pricing by district) is finally approved by the Council of Ministers. The target is for the new tariff to allow 100 per cent recovery of costs for drinking water, but there will probably be room for a subsidy of charges for water for farming use, as the directive allows consideration to be given to the social, environmental and economic effects of the recovery [59].

These increases in water prices will seem to be large in magnitude and painful to the end user. A considerable increase in the end user price of water might put a burden on low-income households. If governmental authorities desire to provide compensation for these extra costs, a direct payment to households in the form of a lump sum would be more adequate [13]. Reducing water prices for low-income households or waiving the extra scarcity price for low water consumption levels is not however advisable, because such subsidies would weaken the overall objective of water conservation.

To determine willingness to pay for water and the costs associated with reduced water deliveries due to scarcity, an estimated price elasticity of water demand is applicable. Schleich and Hillenbrand [60] provide a comprehensive review of empirical findings from residential water demand studies in European countries. In Zachariadis' recent studies [13], a price elasticity of demand of -0.3 is configured and employed, across all non-agricultural sectors (households, industries and tourist sectors), which is approximately the average value from other European studies, in order to perform meaningful econometric analyses. Thus, with this value, the demand for water seems to be inelastic that is, changes in price have a relatively small effect on the quantity of the water demanded. The price elasticity of water is low but is not zero. Consumers therefore can adapt to higher prices, particularly in the medium and long term. In this way it will become easier for consumers to adjust to a future arid climate [61]. For the agricultural sector, which consumes most of the water in Cyprus, determining the potential effect of pricing policies still remains a major topic for further research [13]. In general, water-pricing policies should provide enough incentives for users to use water resources efficiently and thereby contribute to the environmental objectives of the EU Water Directive.

Cyprus has a rich biodiversity, one of the highest in Europe [61]. This biodiversity is currently threatened by the invasion of alien species and epidemics from livestock-borne diseases affecting wildlife [62]. As a measure of managing biodiversity, a register of all species has to be compiled and the species that are sensitive to climate change should be monitored. Alien species must be recorded in order to prevent their expansion. Forests are a special part of the ecosystem and play an important role in keeping a stable global climate as well as offering services and products with economic value. They purify water and influence rainfall patterns, as well as protecting against extreme events, protecting aquifers, improving air quality, and provide shelter to biodiversity [62]. More frequent and severe summer droughts are likely to lead to more extensive forest fires and, eventually, desertification in some areas. Special attention must be given 
to improve forest resilience to fires by classifying forests according to the risk of fire and establishing early warning systems and water supply systems for firefighting.

Further, sea-level rise may reduce habitat availability for bird species. Ecosystems can provide several valuable services that the welfare of humans depends on, such as food, water, energy, purification of water and air, primary production, cultural services and others. Overexploitation of these services and natural resources, have made ecosystems more susceptible to climate change and accordingly less capable of adapting [61]. With respect to water resources, the measures should enhance ecosystem storage capacity, protect surface and groundwater quality, promote good condition of soil, enhance water management, and efficient water use, and implement appropriate water pricing to reflect scarcity and environmental costs.

It is important, therefore, to establish monitoring mechanisms in order to provide much-needed data, which can send early warnings to policy makers and the public and can aid to avoid substantial natural and economic damages.

\section{Water Policy of Cyprus}

Arguably the current water supply situation in Cyprus is not only at a highly critical phase but it is also unsustainable. Water scarcity and ongoing droughts, are damaging the island due to exhaustion of any previous cushioning effect of well-stocked aquifers. A major constituent of water management is to provide security against these multiyear drought periods but also to safeguard the ecosystems. This is not an easy assignment, for three reasons; the obvious provision of additional water through seawater desalination is costly and energy intensive, which, furthermore, produces greenhouse gas emissions that have additional knock on effects for the environment; water use is difficult to monitor, often profligate and appears inequitable, making taxation a complex issue; and finally providing acceptable policies that take into account local, as well as global influences require new evidence to be collated.

To meet the challenge of water scarcity in Cyprus and to plan for future needs, for both domestic and agriculture water supply, it is necessary to design and implement a new water policy accompanied by specific strategies that may be adapted over time. Simple comparison of the supply and demand with regard to the existing water situation is not sustainable due, among other things, to the growth of population, improving living standards, increased number of tourists and, significantly, the increasing demands for irrigation. Secure measures for additional sources of supply must be considered and reduction of waste enforced so that a balance between supply and demand can be achieved which will be sustainable over time, at the least possible cost.

As described in earlier sections, the Government of the Republic of Cyprus has already put in much energy, money, and time in creating desalination plants, adopting recycling water methods, and utilising dams in order to increase water supply capacity. We note that some of the rivers, which to be tapped, flow into the Turkish occupied area and so cooperation with those on the Turkish side is required. Of course, political issues make collaboration a complicated task, hence, it is imperative that on this specific matter, both sides do speak the same language and exchange views in an open environment while at the same time recognising the wider ramifications of actions. 
In the short term, the design of quick, win-win reuse of grey water systems is to be encouraged. Here, simple cost benefit analysis models can be developed locally which identify the best policy and can also be used to enlighten the users. In the light of economic considerations, in the long term, solar powered desalination is surely the way forward for an island without natural energy resources and, therefore, this should be high on the research agenda.

However, this said there is also a need to create new social norms that establish the waste of water as being social unacceptable. In other domains shared knowledge has been shown to help in this regard; perhaps the best example is where residents of a street in Brighton in the U.K. reduced their energy consumption by $15 \%$ in only three weeks by sharing knowledge of their own use [63]. To this end better understanding of water use is needed. This may start with better monitoring of household, agricultural and commercial use. This data may then form the basis of improved predictive models. Here, we suggest a systems approach to understand the total demand for water enabling users to see how their demands collectively accumulate. In other domains the term multi criteria model has been used to describe situations where many influences can be brought to bear on a single issue. Such a model would be useful to engage with the powerful farming lobby groups who demand special attention.

In terms of demand, wider acknowledgement of the true water cost of products is vital. The virtual water concept has now been taken up in different areas, and specifically in Cyprus by Zoumides [14] but, also importantly, we are now able to quantify demand [64,65]. The ability to quantify costs is especially important when we try to investigate future trends of potential rainfall. The work of He [66] shows how we might establish climateproof strategies; further analysis needs to be included to evaluate the cost of doing so [13]. Perhaps, following similar lines to views put forward by Stern [67], based on this econometric analysis, the conclusion may be that Cyprus has to act now.

Noting the problems and constraints of water sources, another basic objective of a water policy of Cyprus and, hence, forming a research for us all, should be to understand the role of appropriate pricing mechanisms, to both reduce demand (and perhaps also to fund additional research) in an equitable manner that does not create a divide between the wealthy, the tourists and local inhabitants. Furthermore, pricing is probably most sensitive for agriculture. Research is needed to quantify advantages of applying irrigation water more in line with actual plant requirements, which would encourage the take up of these new approaches. The same is true for ideas to adjust (to the extent possible) cropping patterns in favour of crops with lower water requirements, or promote crops with considerable less need of irrigation water for their growth and production. In this regard, the farming community is quite powerful but these are decisions to be made by the island as a whole.

There also needs to be more stringent rules to enforce profligate waste or illegal use. This holds for individuals and commercial organisations and also for the agencies providing the water. When coupled with monitoring, models can be used to identify potential illegal water use with rapid court processing encouraged (through new laws) to highlight the problems. If, overnight, countries can change their behaviour towards smoking in public places, then why can we not change the way in which we use water?

Ideally a single water entity would be created to reduce losses of domestic water from urban water supply distribution systems, to increase the efficiency of domestic use, to explore possible rainwater 
utilisation, to intensify water saving promotion campaigns, to provide financial incentives for saving potable water, to maintain and enhance the quality of water and to continue the efficient management procedure. However, this is a complex issue since understanding the balance of the economy offsetting tourism against agriculture is not straightforward. Even the balance between reward and taxation is not simple to achieve. If shortages are here to stay then the effects of the recent water rationing of water for both irrigation and domestic use, to safeguard the existing scarce water resources, needs to be investigated. More analysis is required on how pricing links with, and receives feedback from, the other elements that make up the water system. A multi-tiered pricing could be the answer to encourage efficient use. Studies of pricing and utility management in general have already been performed [68] by those who advocate an integrated water resource management system, and indeed have incorporated climate changes using this integrated approach [69], but here we propose that such an integrated system should include additional factors, such as migration as well as the social aspects of the political system itself. We note that in other places, such as Holland, it has been shown that ground water tax systems do not always work [70] and, therefore, more work is required to understand how water pricing and tax can be incorporated into a mathematical model and not just seen as a stand-alone consideration. We therefore recommend a meta-model, which would essentially be a system of systems with demand, migration, energy considerations and more, each feeding into a highly interactive and dynamic model to help us understand the hidden complexities of our social and technical systems. Hence, this model would be closer to the integrated assessment models as used in the analysis of climate change with agent based sub models and methods of cost benefit analysis each slotting into the meta model. The important aspect is openness to allow others to "experiment" with the model.

To achieve these objectives from a policy perspective, it is necessary to develop an appropriate strategy based upon an evaluation of the potential options that might be available using criteria that include effectiveness, competency, fairness, public health, environmental impact, political and public acceptability, sustainability, international effects and others. However, some of these issues are the hardest to quantify and hence difficult to include in models, which can be used to forecast behaviour. Hence, in this case, the mathematical models may still be useful to guide us acting as a decision support system rather than predicting precise response.

This brings us to the question that naturally arises of how to justify any policy changes or policy actions to the general public. What can scientists do to help provide a social legitimacy for any actions taken? To answer this point we need to develop new, open tools to support decision-making as well as capture existing methods, which cover the various elements that make up the system that is water resource management. Part of this "global" system is social, part infrastructure, part climate and part political. Critically, from a mathematical perspective is the issue of how we combine models from each of these areas in order to be able to make forecasts and predictions about future states allowing decision makers to run "what if?" scenarios to test out policy decisions prior to implementation [71].

Importantly, if we can create a global model incorporating all pertinent factors then with such a complicated system, the outcomes will not be unique, nor precise. Education needs to be improved to show us how to make difficult decisions in uncertain situations such as this. In order to safeguard against 
future events we need to understand how to build in some insurance aspects to govern the risk management of decisions along the lines of Perez Blanco and Gomez [72].

In other areas, to consider acceptance of policy by groups of people and incorporate migration trends as well as other aspects, new methods of agent based modelling have successfully been introduced [73]. These simulation-based methods are good for demonstrating to a wider range of users, the outcomes from systems in a graphical way. The way in which the simulation is developed allows for feedback between factors so that a dynamic analysis is possible which goes a step further that the static analysis typically produced for most econometric models. To validate such models, data becomes a key factor, which takes us back to the issue of monitoring. In this regard, there now exists improved data for water systems with methods already tried and tested to incorporate this data into an intelligent - or probably now called - smart support system for infrastructures that manage the water systems [74].

The task ahead is thus not simple. Mathematical models are extremely useful to allow us to gauge future conditions but finding one that covers local aspects, within Cyprus say, while at the same time encapsulating global features such as energy costs, global migration and social mobility, is not going to be an easy task. Factor in the need to consider political as well as commercial interests makes the challenge even harder if we are to provide new tools to support our decision makers.

\section{Conclusions}

Water is by far the most precious resource in Cyprus. In view of both the significance of water in the quality of life and in the economic development of a country, then in the face of potential extreme scarcity of water it is vital that a national Water Policy be redefined for Cyprus in order to guarantee the sustainability of the islands water resources and investments.

In spite of the impressive development of conventional surface sources in the last four decades in Cyprus, there is still a lot that remains to be accomplished in the realm of water resources and management. Future political developments in Cyprus will both affect and be affected by water resource management since both the Greek and Turkish communities substantially draw upon the same groundwater aquifer in certain parts of the island.

Here, we have presented the current water situation in the island and examined the implications on the demand and supply side of water under the transformations of environmental changes, urbanisation and economic development. The strategic measures undertaken by the Government of the Republic of Cyprus and the national water stakeholders so that water resource management becomes more sustainable are discussed and assessed. Alternative methods used to make up for the constantly declining yields of water reservoirs are additionally considered.

One of the suggestions of this study is that Cyprus should follow the underlying principles of the virtual water concept and shift to a low water consuming economy, both in general but for the agricultural sector in particular. For this purpose, a different cropping pattern should be considered and be selected in view of the climatic conditions and the increasing water scarcity of the country. Ideally a system of 
systems should be created so that we can bring in to our consideration all the factors that influence water resource management.

No single option will resolve the Cyprus water problem. It would be difficult to rank individual options in order of their acceptability following conventional economic criteria, however if an attempt was made then it is believed that water hierarchy should be the pinnacle. The idea of water hierarchy means that one should exploit fully the potential for water savings through increased water efficiency before considering increasing supply through additional infrastructure.

Finally, Cyprus is not the only dry spot on Earth. Other countries worldwide are also suffering from similar limited water availability and it only seems wise and beneficial to collaborate and learn from their valuable experiences and adaptive strategies on how they approach and overcome the specific obstacles of water scarcity.

\section{Acknowledgements}

The authors are grateful for the constructive and helpful comments of the anonymous reviewers.

\section{Author Contributions}

Both authors contributed to the development of this paper. Anastasia Sofroniou gathered all data information, analysed results and prepared the first draft of the paper. Steven Bishop improved the discussion section and revised the manuscript.

\section{Conflicts of Interest}

The authors declare no conflict of interest.

\section{References}

1. World Water Day (2007) - Coping with Water Scarcity, Challenge of the Twenty First Century. Available online: http://www.fao.org/nr/water/docs/escarcity.pdf (accessed on 29 August 2014).

2. Falkenmark, M.; Berntell, A.; Jägerskog, A.; Lundqvist, J.; Matz, M.; Tropp, H. On the Verge of a New Water Scarcity: A Call for Good Governance and Human Ingenuity; SIWI Policy Brief; Stockholm International Water Institute: Stockholm, Sweden, 2007.

3. Hatami, H.; Gleick, P.H. Water, war, and peace in the Middle East. Environment 1994, 36, 6-15.

4. Starr, J.R. Water wars. Foreign Policy 1991, 82, 17-36.

5. Bixio, D. Cyprus without Water? One Island, One Problem and Some Related Challenges; European Commission: Brussels, Belgium, 2008.

6. Raso, J. Updated Report on Wastewater Reuse in the European Union; European Commission: Brussels, Belgium, April 2013. 
7. Ohlsson, L.; Turton, A.R. The Turning of a Screw: Social Resource Scarcity as a Bottle-Neck in Adaption to Water Scarcity. Available online: https://www.soas.ac.uk/water/publications/papers/ file38362.pdf (accessed on 29 August 2014).

8. Chave, P. The EU Water Framework Directive: An Introduction; International Water Association Publishing: London, UK, 2001.

9. Intergovernmental Panel on Climate Change-AR4. Available online: http://www.ipcc.ch/ (accessed on 29 August 2014).

10. Christensen, J.H.; Christensen, O.B. A summary of the PRUDENCE model projections of changes in European climate by the end of this century. Clim. Chang. 2007, 81, 7-30.

11. Giorgi, F. Climate change hot-spots. Geophys. Res. Lett. 2006, 33, doi:10.1029/2006GL025734.

12. Gao, X.; Giorgi, F. Increased aridity in the Mediterranean region under greenhouse gas forcing estimated from high resolution regional climate projections. Glob. Planet Chang. 2008, 62, 195-209.

13. Zachariades, T. Residential water scarcity in Cyprus: Impact of climate change and policy options. Water 2010, 2, 788-814.

14. Zoumides, C. Virtual Water Trade and the Water Footprint of Cyprus: Alternative Tools in Managing Water Resources. Master's Thesis, University of Edinburgh, Edinburgh, UK, December 2008.

15. Water Development Department (WDD)—Annual Report 2012. Available online: http://www.cy prus.gov.cy/moa/wdd/wdd.nsf/All/7CE27F150F36B001C2257B7A00297B82/\$file/GRAND\%20FIN AL-ENGLISH-2012.pdf?OpenElement (accessed on 29 August 2014).

16. International Monetary Fund (IMF) —World Economic Outlook Database. Available online: http://www.imf.org/external/country/cyp (accessed on 29 August 2014).

17. World Bank Group Homepage. Available online: http://www.worldbank.org (accessed on 29 August 2014).

18. Cystat. Agriculture Statistics; Cyprus Statistical Service: Nicosia, Cyprus, 2007.

19. Vörösmarty, C.J.; Green, P.; Salisbury, J.; Lammers, R.B. Global water resources: Vulnerability from climate change and population growth. Science 2000, 289, 284-288.

20. Kummu, M.; Ward, P.J.; de Moel, H. Varis, O. Is physical water scarcity a new phenomenon? Global assessment of water shortage over the last two millennia. Environ. Res. Lett. 2010, 5, doi:10.1088/1748-9326/5/3/034006.

21. Boufaroua, M.; Albalawneh, A.; Oweis, T. Assessing the efficiency of grey water reuse at household level and its suitability for sustainable rural and human development. Br. J. Appl. Sci. Technol. 2013, 3, 962-972.

22. Water Balance for Cyprus. Available online: http://www.moa.gov.cy/moa/wdd/Wdd.nsf/balance_en/ balance_en?OpenDocument (accessed on 29 August 2014).

23. Water Development Department Homepage. Available online: http://www.moa.gov.cy (accessed on 29 August 2014).

24. Hochstrat, R.; Kazner, C. Flexibility of Coping with Water Stress and Integration of Different Measures; Case Study Report Cyprus of European Commission Funded Project Technology Enabled Universal Access to Safe Water (TECHNEAU): Brussels, Belgium, 2009. 
25. Pashiardis, S. Trends of precipitation in Cyprus rainfall analysis for agricultural planning. In Proceedings of the 1st Technical Workshop of the Mediterranean Component of CLIMAGRI Project on Climate Change and Agriculture, Rome, Italy, 25-27 September 2002.

26. Meteorological Service - Cyprus Average Annual Precipitation Report, 1901-2011. Available Online: http://www.moa.gov.cy/moa/ms/ms.nsf/DMLclimet_reports_en/DMLclimet_reports_en?opendocum ent (accessed on 29 August 2014).

27. Giannakopoulos, C.; le Sager, P.; Bindi, M.; Moriondo, M.; Kostopoulou, E.; Goodess, C.M. Climatic changes and associated impacts in the Mediterranean resulting from a $2{ }^{\circ} \mathrm{C}$ global warming. Glob. Planet Chang. 2009, 68, 209-224.

28. Cassardo, C.; Jones, J.A.A. Managing water in a changing world. Water 2011, 3, 618-628.

29. Socratous, G. Management of Water in Cyprus. Available online: http://www.moa.gov.cy/ moa/wdd/WDD.nsf/0/8178831B22DD87F2C2256EAC0038E2CE/\$file/Pages\%201-9.pdf (accessed on 29 August 2014).

30. Panayi, A. Use of a public perceptions study to assist policy making for reclaimed water reuse. In Proceedings of the 13th International Conference on Environmental Science and Technology, Athens, Greece, 5-7 September 2013.

31. Cystat. Demographic Report; Cyprus Statistical Service: Nicosia, Cyprus, 2012.

32. Artemis, C. Country report, Cyprus. In Proceedings of the Conference of the Water Directors of the Euro-Mediterranean and South-eastern European Countries, Athens, Greece, 6-7 November 2006.

33. Wulf, K. Reassessment of the Islands Water Resources and Demand; Synthesis Report FAO/WDD TCP/CYP/2801; Ministry of Agriculture, Natural Resources and Environment of the Republic of Cyprus: Nicosia, Cyprus, June 2002.

34. Demetriou, C.; Georgiou, A. Management of groundwater resources in Cyprus-Harmonisation with the EU Water Framework Directive. In Proceedings of the BALWOIS 2004 Ohrid, FY Republic of Macedonia, 25-29 May 2004.

35. Water Framework Directive (WFD) - Annual Report. Ministry of Agriculture, Natural Resources and Environment of Republic of Cyprus: Nicosia, Cyprus, 2005.

36. Water Development Department (WDD) -Annual Report 2013. Available online: http://www. cyprus.gov.cy/moa/WDD/WDD.nsf/A11/0C2D1E1836A2F4FCC2257CE7002C8173/\$file/Etisia_en_ 2013.pdf?OpenElement (accessed on 29 August 2014).

37. Meeting of the Cyprus Institute for the Cogeneration of Electricity and Desalinated Water Using Solar Energy. Simerini Newspaper, 21 August 2010, p. 37. (In Greek)

38. Thrasivoulou, P.; Patsalosavvis, K.; Zafirakou, A. Water supply management in Cyprus under climate uncertainty. In Proceedings of the International Conference Adapt to Climate, Nicosia, Cyprus, 27-28 March 2014.

39. Water Development Department (WDD) -Annual Report 2009. Available online: http://www. cyprus.gov.cy/moa/wdd/wdd.nsf/All/1FDEC883CE0C6483C22577B300267FDE/\$file/Annual_2009. pdf?OpenElement (accessed on 29 August 2014). 
40. Birol, E.; Koundouri, P.; Kountouris, Y. Farmer's demand for recycled wastewater in Cyprus: A contingent valuation approach. In Wastewater Reuse-Risk Assessment, Decision-Making and Environmental Security; Zaidi, M.K., Ed.; Springer Netherlands: Heidelberg, Netherlands, 2007; pp. 267-278.

41. Cyprus Tourism Organisation Homepage. Available online: http://www.visitcyprus.com (accessed on 29 August 2014).

42. Guidelines for Meeting the Cyprus Tourism Organization Minimum Standards for Sustainability in Hotel Establishments. Available Online: http://www.visitcyprus.com/media/b2b_en/Tourism_ Services/Guidelines_Sustainablity_hotels_EN.pdf (accessed on 29 August 2014).

43. Savvides, L.; Dorfinger, G.; Alexandrou, K. Re-Assessment of the Water Resources and Demand of the Island of Cyprus: The Assessment of Water Demand of Cyprus; TCP/CYP/8921; Water Development Department: Nicosia, Cyprus, October 2001.

44. Karatas, E.; Kuhlwein, E. Climate Change-A Challenge for Europe and Cyprus; tredition GmbH: Hamburg, Germany, 2010.

45. Fayssal, N. The Impact of Virtual Water Trading on the Water and Agricultural Policies in the Semi-Arid Regions; The Case Study of Cyprus; ATINER's Conference Paper Series AGR2013-0769; Athens Institute for Education and Research: Athens, Greece, 18 December 2013.

46. Tsiourtis, N.; Photiou, C.; Hajispyrou, E.; Pashardes, P; Rostandi, N. Chapter 15: Application of the Drought Management Guidelines in Cyprus. Available online: http://www.iamz.ciheam.org/ medroplan/guidelines/examples_cyprus_planning.html (accessed on 29 August 2014).

47. Cystat. Statistics on Tourism; Cyprus Statistical Service: Nicosia, Cyprus, 2009.

48. Adaption to Climate Change in the Agricultural Sector, AGRI-2006-G4-05, AEA Energy and Environment and Universidad de Politecninca de Madrid; Report to European Commission Directorate-General for Agriculture and Rural Development, ED05334, Issue Number 1; AEA Energy \& Environment: Oxford, UK, December 2007.

49. Metochis, C.; Eliades, G. Irrigation systems in Cyprus. In Agricultural Research Institute Review for 2000-01; Agricultural Research Institute: Nicosia, Cyprus, 2002; pp. 101-105.

50. Allan, J.A. Fortunately there are substitutes for water otherwise our hydropolitical futures would be impossible. In Priorities for Water Resources Allocation and Management; Overseas Development Administration (ODA): London, UK, 1993; pp. 13-26.

51. Wada, Y.; Beek, L.P.H.; Bierkens, M.F.P. Modelling global water stress of the recent past: On the relative importance of trends in water demand and climate variability. Hydrol. Earth Syst. Sci. 2001, 15, 3785-3808.

52. Zoumides, C.; Zachariadis, T. Irrigation water pricing in southern Europe and Cyprus: The effects of the EU common agricultural policy and the Water Framework Directive. Cyprus Econ. Policy Rev. 2009, 3, 99-122.

53. Zoumides, C. Incorporating the water footprint into national water management policy. Presented at Frederick University, Nicosia, Cyprus, 18 March 2010. 
54. Papasolomontos, A. Appendix 4: Country case study-A framework for the development of a water policy review for Cyprus. In Proceedings of the Second Expert Consultation on National Water Policy Reform in the Near East, Cairo, Egypt, 24-25 November 1997.

55. Photiou, C. Wastewater treatment and environment. In Proceedings of the International Conference on Integrated Water Management: Policy Aspects, Nicosia, Cyprus, 19-21 June 2003.

56. Hadjigeorgiou, P. Implementation of the Water Framework Directive in Cyprus. In Proceedings of the 4th ECCE Meeting, Larnaca, Cyprus, 17-18 October 2008.

57. Omorphos, C. Addressing the challenge of water scarcity in Cyprus. In Proceedings of the International Conference and Exhibition on Global Water Efficiency 2008, Limassol, Cyprus, 27-28 November 2008.

58. Kelay, T.; Vloerbergh, I.; Hagegård, K.; Chenoweth, J.; Capelos, T.; Fife-Schaw, C. Consumer Focus Groups; Technology Enabled Universal Access to Safe Water (TECHNEAU): Brussels, Belgium 2009.

59. Charalambous, C. Water prices could double by year end. Cyprus Mail Online Newspaper, 12 March 2010.

60. Schleich, J.; Hillenbrand, T. Determinants of residential water demand in Germany. Ecol. Econ. 2009, 68, 1756-1769.

61. Zachariadis, T. Climate change in Cyprus: Impacts and adaptation policies. Cyprus Econ. Policy Rev. 2012, 6, 21-37.

62. Fifth National Report to the United Nations Convention on Biological Diversity: Cyprus; Ministry of Agriculture, Natural Resources and Environment of Republic of Cyprus: Nicosia, Cyprus, August 2014.

63. Nudge technology gently persuades residents to go greener. Available online: http:/www. open.ac.uk/about/showcase/article/nudge-technology-gently-persuades-residents-go-greener (accessed on 1 September 2014).

64. Polycarpou, A.; Zachariadis, T. An econometric analysis of residential water demand in Cyprus. Water Resour. Manag. 2013, 27, 309-317.

65. Chenoweth, J.; Hadjikakou, M.; Zoumides, C. Quantifying the human impact on water resources: A critical. Hydrol. Earth Syst. Sci. Discuss. 2013, 10, 9389-9433.

66. He, X. Mainstreaming adaptation in integrated water resources management in China: From challenge to change. Water Policy 2013, 15, 895-921.

67. Stern, N. Stern Review on the Economics of Climate Change; HM Treasury: London, UK, 2006.

68. Stedman, L. Water-Scarce Cyprus leads discussions on utility management and pricing. Water Util. Manag. Int. 2012, 7, 18-20.

69. Hejazi, M.I.; Edmonds, J.; Clarke, L.; Kyle, P.; Davies, E.; Chaturvedi, V.; Wise, M.; Patel, P.; Eom, J.; Calvin, K. Integrated assessment of global water scarcity over the 21 st century-Part 1: Global water supply and demand under extreme radiative forcing. Hydrol. Earth Syst. Sci. Discuss. 2013, 10, 3327-3381.

70. Schuerhoff, M.; Weikard, H.P.; Zetland, D. The life and death of the Dutch groundwater tax. Water Policy 2012, 15, 1064-1077. 
71. Hunt, J.C.R.; Timoshkina, Y.; Baudains, P.J.; Bishop, S.R. System dynamics applied to operations and policy decisions. Eur. Rev. 2012, 20, 324-342.

72. Pérez-Blanco, C.D.; Gómez, C.M. Insuring water: A practical risk management option in water scarce and drought-prone regions? Water Policy 2014, 16, 244-263.

73. Helbing, D. Understanding Complex systems. In Social Self-Organization; Springer-Verlag: Berlin, Germany, 2012.

74. Kazeli, H.; Keravnou, E.; Christofides, T.C. An intelligent hybrid decision support system for the management of water resources. Int. J. Pattern Recognit. Artif. Intell. 2003, 17, 837-862.

(C) 2014 by the authors; licensee MDPI, Basel, Switzerland. This article is an open access article distributed under the terms and conditions of the Creative Commons Attribution license (http://creativecommons.org/licenses/by/4.0/). 